\title{
'Nothing dirty about turning on a machine': Loving your Mechanoid in Contemporary Manga
}

\author{
John Stephens and Mio Bryce
}

\author{
If something not human has emotions ... then it \\ would be considered sentient - alive - just like \\ a human. If it's the same as a human, it wouldn't \\ be wrong to love that thing. \\ (Chobits 8, p.93)
}

$\mathrm{T}$ The relationships in contemporary manga and animé between humans and humanoid machines — robots, androids and physical embodiments of computer programs - render permeable the boundary between human and machine, nature and culture, born and made. The distinction between human and machine ceases to be clear-cut as, on the one hand, artificial intelligence entities are depicted with evolving sentience and a capacity for emotional development and, beyond that, for subjective agency, and, on the other hand, people become 'cyborged' under social and/or familial pressures to perform the roles expected of them, and basic human communication is mediated through technology ${ }^{1}$. In questioning assumptions about the fixity of human nature, this body of work conforms with what Elaine Graham has identified as a 'scrutiny of the basic assumptions on which matters such as personal identity, the constitution of community, the grounds of human uniqueness and the relationship between body and mind are founded' (Graham 2002, p. 2). Further, though, romantic narratives about a boy and the female mechanoid ('mecha') who comes into his life and transforms it are used thematically not to predict visions of a golden technological future, but to reassert a pattern of heterosexual bonding grounded in love, nurture and monogamy ${ }^{2}$. Napier (2000) argues that this conservative impulse is a reaction against the increasing power of women in contemporary Japanese society, whereas Kumiko Sato argues that the maternal function attributed to the popularized form of female cyborgs and androids who save a powerless male hero is an aspect of the postwar Japanism which asserts Japanese uniqueness in its blending of traditional culture and new technology (Sato 2004, p.354). The reaffirmation of traditional social values under threat is underpinned by a more or less explicit dependence throughout boymeets-mecha stories on an ancient folktale motif, that of the heavenly bride, or swan maiden, ${ }^{3}$ and hence the stories can be seen as cyborg-age fairy tales. In this paper, we explore these narrative and thematic elements with particular reference to CLAMP's Chobits manga series (8 volumes, 2001-2002) ${ }^{4}$, making some comparisons with Ken Akamatsu's manga A.I. Love You ${ }^{5}$, and Masakazu Katsura's Video Girl Ai manga series (13 volumes, 1990-1992)6. To ground our discussion of the heavenly bride schema, we will make some reference to Kōsuke Fujishima's animé Ah! My Goddess (2000), an eclectic articulation of Asian, Norse and Christian mythologies into a representation of a universe organized as a blend of mystic power and digital programming. This film - an offshoot of a popular TV animé series - does not strictly belong to the 'boy meets mecha' narrative schema we are primarily concerned with, but offers clear evidence for the currency of the heavenly bride schema in contemporary manga and animé.

Ultimately, the schema is a redeployment for younger audiences of a character configuration that, Kumiko Sato (2004, pp.348-49) argues, originated in cyberpunk and was thence taken up in manga: a Japanese female hero linked with an inept male figure who is weaker and more human than her. By the late-1990s, Sato notes, 'female cyborgs and androids have been safely domesticated and fetishized into maternal and sexual protectors of the male hero', and their function 'is usually reduced to either a maid or a goddess obediently serving her beloved male master, the sole reason for her militant nature'. Sato also argues that the reduction of strong female cyborgs to maternal guardians 'seems symptomatic of Japanese identity concerning both race and gender' (p.349). While this configuration is clearly present in the texts we are concerned with, they seem already to have moved to a more self-reflexive phase and now interrogate and even satirise the convention, especially its implications for gendering. For example, in episode 31 (vol. 4) of Akamatsu's A.I. Love You the cyborg Saati decides that human Hitoshi misses his mother, and attempts to play the role: Hitoshi is comically infantilised, to the point that Saati resolves to attempt to breastfeed him (and hence inadvertently to satisfy his sexual desire). The circumvention of the possibility, however, connects the incident with a more pervasive theme of rethinking gender attitudes.

The manga which are the focus of this study are marketed primarily for boys: Video Girl Ai, for example, targets an audience of Junior High School age ${ }^{7}$, while the Chobits ${ }^{8}$ audience is more mid-teen and up. There is also a substantial 
female readership, which displays two responses: one is to dismiss such series as representing a typical male point of view ${ }^{9}$, whereas the other is to find alignment with the good-hearted innocence portrayed in the principal female characters (as indicated by reader responses included in the peritext of Video Girl Ai, vol. 12, p.182 and vol. 13, pp. 188-189). This reflects a dual perspective on the heavenly bride schema, the re-emergence of which in manga and animé high-tech fantasies is perhaps explained by the need for a new Bildungsroman in Japan. As Jungian psychologist Hayao Kawai suggests, a Japanese ego is symbolised by female heroes as found in Japanese folktales, whereas (following Neumann) male heroes reflect a modern European ego (Kawai 1982, pp.25-26). The idea of the 'perfect match' implicit in the heavenly bride schema exists as a powerful metanarrative, particularly in girls'/ women's literature, although it seems to have increased in prominence for the affluent younger generation, which has grown up surrounded by the simulacra of information technology and distanced from their own corporeality, emotions and individual subjectivities. Love, as a profound interaction with another integral, individual subjective agent, is a remote ideal. Saito (1996, pp.170-194) and Murakami (1998, p.68) see Video Girl Ai as an example of learning 'love' through simulation, much like a role-play game. Ōhira, offering a psychiatrist's perspective, argues that young people suffer mental problems because of their longing for an unrealistic 'pure love' (Ōhira 2000), and Yokomori contends that manga are responsible for imprinting readers with an unrealistic ideal of pure love - the belief that the perfect match is both 'real' and 'possible' (Yokomori 1996).

The heavenly bride schema pivots on two characters: a young man, who is usually poor, something of a social outsider, but possessed of a good heart; and a divine maiden (tennyo) who makes an unexpected appearance and becomes the young man's wife/partner. In some versions, the maiden is effectively captured by the man, who steals and hides her hagoromo (that is, a feathery/gossamer robe), but in others she is drawn or sent to him because of his need and worthiness. Usually, the relationship is only temporary, as the maiden will eventually return to the heavens ${ }^{10}$. Thus the TV series $A h$ ! My Goddess relates the adventures of a heavenly girl, the first class goddess
Belldandy, with a gentle, kind yet ordinary human boy, Keiichi Morisato, a freshman at Nekomi University of Technology. While attempting to order a fast food delivery, Keiichi inadvertently dials the Relief Goddess Office, leading to Belldandy's sudden emergence from a mirror into his dormitory room. When Belldandy offers to grant him a wish, and he asks for a girlfriend just like her to stay with him forever, she vows to stay with him as long as he needs her. Keiichi is promptly expelled from his dormitory room (where, needless to say, girls are not allowed), but Belldandy uses her divine power to restore an old, deserted temple, where they settle down and are joined by Keiichi's younger sister, Megumi Morisato, and later by Belldandy's elder sister Urd, and then younger sister Skuld. The TV series focuses on the slow and tantalising development of romance between the shy, innocent wouldbe lovers, Belldandy and Keiichi, entangled with comic incidents, often caused by the provocative, forceful Urd and Keiichi's various fellow students. The film takes this situation as given, and deals instead with an attempt by Belldandy's former mentor, Celestin, to overthrow the heavens by using Belldandy as a conduit to introduce a powerful virus that will cause the computer network which sustains the universe to crash. While he is clearly out of his depth in the struggle for control of the universe, Keiichi's love for Belldandy is unwavering, and he is rewarded by her decision at the close of the film to make her life with him permanently.

A summary (or, better, travesty) version of this schema is presented by the main character of Chobits: 'A guy finds a nice girl, takes her home... She's always cute. Then it turns out she's got some sort of special powers ... and she'll fall madly in love with the guy! She'll do all sorts of things — cooking, cleaning ... and other stuff. Happens all the time. I've seen it on TV!' (1, pp.40-41). It takes a long time for Hideki to recognise the missing component of the schema: 'I can't assume that she'll always be around' (7, p.61). As implied by this summary, the principal female characters in the 'boy meets mecha' narratives share many of Belldandy's characteristics: they are beautiful, endowed with superior powers, appear unexpectedly, and their stay is possibly temporary. Although they are fully female, their cuteness (with its associated purity, innocence, fragility and childlike comicalness ${ }^{11}$ is emphasised and there is a 


\section{Again the need for critical analysis of the ways in which the strangeness is recuperated into the commonest, most 'universal' contemporary belief of all - all you need is love.}

barrier against any consummated sexual relationship. In the cases of Chii (Chobits) and Ai (Video Girl Ai) their propensity for appearing clothed in floating dresses evokes images of the hagoromo, and hence of their non-human origin and always imminent departure, in that the hagoromo has the power to erase the wearer's memory of her life as a human. Ai's role is represented by her name, Ai Amano (literally, 'Love Heavenly-field'), both in her angelic role in attempting to promote love between others, but also because she is ultimately herself the representation of love as a heavenly bride.

At the centre of these narratives is a machine which has a human (female) appearance, an artificial intelligence, and is programmed to learn human emotions. Above all, unique subjectivities can be ascribed to, and claimed by, these mechanoids, and this is a key component in attributing humanity to them. The affirmation that 'It doesn't matter if your programming is computer code or DNA - you are unique' (Chobits 7, p.22) is matched by equivalent assertions in, for example, A.I. Love You. When Saati, an embodied computer program, suggests she can be simply reconstructed if erased, her creator (and would-be lover) remonstrates, 'No, Saati! There'll only be one of you. Even if the body and the face are the same...to me, you're the only real Saati out there!'(A.ILove You 1, p.177). When, in Video Girl Ai, Yōta is faced with the re-programmed Ai who now mechanically performs the role of 'perfect video girl', he grieves, thinking, 'There is no Ai here. She has gone' and tells her, 'I lost the person I loved' (13, p.134). The blurring of the concepts 'human' and 'cyborg/mechanoid', which is familiar in the contemporary world because of our reliance on, and integration of, artificial parts in human bodies, and the extension of human bodies by such mechanical supplements as cars, phones, computers, and so on, develops a new slant when subjectivity and narrative point of view are attributed to a mechanoid character. In the Chobits' world, the materialistic border between human bodies and persocoms (biocomputers in human shape and modelled on organic processes) is clear and definite. Even though Chii is close to human in terms of her emotions and subjectivity and feels emotional pains in her chest, her body remains mecha. She does not eat and has no bodily senses/feelings, such as taste and temperature. The world of Video Girl Ai is more whimsical. A video girl is created by information technology, and endowed with a perfect, sensory feminine body, but lacks emotions. Although they exist only while the videotape is running, they are more perfect materialisations of a human body than Chii. Thus during the time Ai lives in a tent in a park (in order not to disturb Yōta's life, but simply to wait until her video runs out and she disappears), she suffers hunger, fever, bodily disorders and people's laughter and suspicions when she goes to a public bath. She deplores that she must endure human-like physical conditions, although she is not human and does not menstruate (10, p.132). Characters which fit Gray's (2002, p.2) description of a cyborg as 'a self-regulating organism that combines the natural and artificial together in one system', and which mixes 'the evolved and the made, the living and the inanimate', thus attract reader empathy (but not reader alignment, since the audience is envisaged as occupying a young male subject position). Viviane Casimir(1997, p.279) takes the argument further by suggesting that the cyborg not only becomes a metaphor of the blurring of any dichotomy, but also stands for 'the discursive space where a crisis occurs - a crisis of postmodern thought, a crisis in the representation of the "living" or what it means "to be alive". The Chobits volumes engage with such issues explicitly by playing on a version of the 'stranger in a strange land' motif, in that its principal male character, Hideki Motosuwa, is an ingenuous young man fresh from the countryside, who has never even seen a persocom. His rural innocence is more strongly accentuated in the animé version, in which the establishing scene, instead of the postmodern city, is a timeless but archaic countryside, where Hideki wears denim overalls and tends cattle by hand. He is 'honest and kind ... at once both simple and profound' (Chobits 8, p.104), poor, and absolutely computer illiterate. The postmodern society of twenty-second century Tokyo thus impacts upon him like an alien world.

The crisis in the representation of what it means 'to be alive' confronts Hideki soon after his move to the city to attend a cram school, when he finds a persocom apparently thrown out with other rubbish. After much trial and error he manages to activate 'her' - and much is made of the shock to his innocence and naivety when he finally works out that the hard-to-find on-switch is her clitoris (unlike ordinary persocoms, whose switches are usually in their ears). His 
attempt to rationalise the sexual joke over how to turn her on is the first sign of the human/machine blurring: 'What am I doing? She's just a machine, right? Nothing dirty about turning on a machine. Everyone needs a computer' (1, p.23). Chii, as he names her, is a mysterious mechanoid, able to function without an operating system, but deprived of memory, yet programmed with an extraordinary capability to control other persocoms. Once activated, she immediately begins to learn, and quickly develops her knowledge as well as personality, while her affection towards Hideki, intense from the moment he awakens her/switches her on, likewise grows.

The story line is very elaborate, interlacing several problematic relationships amongst the characters Hideki encounters both in his day-to-day life and his quest to understand the mystery of Chii, and embedding as an extended mise en abyme a discrete retelling of the HidekiChii story in a Dick Bruna style series of picture books whose theme is the quest for 'the someone just for you' who will erase the distinction between human and machine. The capacity for forming intersubjective love relationships is a central plank in defining an entity as human, and Chobits effectively posits that here the distinction between computer code programming and DNA programming dissolves: the biologically human lack humanity if incapable of love. The story's various relationships function as commentary on the emerging love between Hideki and Chii. They comprise: a relationship between a student and his teacher, who has been forgotten by her persocom-obsessed husband; the love of a young girl for an older man, who had previously 'married' his persocom (subsequently 'killed' in a traffic accident); a young boy's familial relationship with a persocom he has built in the image of his dead sister, and programmed with aspects of her personality; and, finally, the love between two persocoms especially built to prevent the running of a mysterious program within Chii's system, but who overthrow their own programming to allow her to reach full intersubjectivity, thereby changing the possible futures of all persocoms by freeing them from the laws governing robots and enabling them to share her quest for love, individual being and subjective agency.

A motif which recurs across several boy-meets-mecha narratives is the kidnap or capture of the mecha by a male who is characteristically a warped genius so bonded with technology (so cyborged, indeed) as to have no grasp of human emotions. In Chobits this is foreshadowed by an episode in which, early in her awakening, Chii goes in search of paid work and is lured away to perform in a peep show (Volume 2). She lacks the sexual knowledge and selfawareness to perform the required strip tease, so the show manager tries to teach her how to simulate masturbation. Chii's resistance to the attempt is dramatic, and in the story's first demonstration of the enormous power she is endowed with all persocoms are temporarily shut down. This complex episode is the first assertion of the theme of monogamous love, since the only person who may touch Chii intimately is the one who truly loves her (3, pp.145149). Moreover, in contrast to the sexploitation of the strip show, it is further asserted that the decision will be Chii's and constitute an assertion of subjective agency.

A thematic development of this episode occurs when Chii is kidnapped by technology whiz-kid Yoshiyuki, who thinks such a machine is wasted on a computer illiterate like Hideki. Yoshiyuki is the epitome of the human effectively transformed into a cyborg (a persocom meshes with its owner by being a mobile phone, calculator, computer, and household servant), and lusting after Chii's machineness, he is ever oblivious to her human aspect. When Yoshiyuki also attempts to insert a finger into Chii's vagina, the scene forcefully restates her quest: 'You are not "the person just for me". So do not come inside me' (5, pp.76-77). She emits a force so powerful as to render him unconscious and entangle him in the multiple leads he was using to connect her to twenty-four other persocoms in an attempt to decrypt her source code.

Chii's uniqueness is grounded in her creation as a 'chobit', a mechanoid so advanced as to have the potential to evolve human subjectivity as the interactive product of a self-learning program and environment - a trait shared with Major Kusanagi in Ghost in the Shell and Tima in Tezuka's Metropolis. Her forceful defence of her subjective integrity, moreover, puts her into direct opposition to the 'laws' of robotics, though this involves a rather complex dialogism. In both 'kidnap' incidents, it is implicit that Chii must comply with what is asked of her or breach the second 'law' (a robot must obey the orders given it by human 


\section{Deconstructive critical work is just as significant as it ever was.}

beings). Because the audience (for both manga and animé) is positioned so as to be empathetic with Chii, the attacks on her sexual integrity are readily interpreted as sexual abuse of a human being. That her self-defence only partially complies with the third 'law' (a robot must protect its own existence - as long as such protection does not conflict with the first or second law), since she refuses an order, and that, in temporarily disabling Yoshiyuki, she breaches a clause of the first 'law' (a robot may not injure a human being), are important steps toward establishing her human status: the 'laws' of robotics function to maintain human superiority over mechanoids. Chobits is explicit in stating that the creator of the persocoms 'didn't want them to be bound by the three laws of robotics' (8, p.127), a freedom extended beyond Chii. Zima, the data bank designed to obstruct Chii's program, breaks the first two laws (a robot may not injure a human being, or allow a human being to come to harm; a robot must obey the orders given it by human beings) in his refusal to intervene to prevent Chii's potentially dangerous program from running - a program which could restore machines to the objective and quasi-solipsistic state of machines we know, or enable the accession of subjective agency by machines (as articulated by Zima when he argues that endowing persocoms with a capacity for love enables them to love each other).

Mechanoids freed from the laws of robotics and attributed with subjective agency challenge our concepts of humanity and posthumanity: if such an entity performs humanity, and that performativity embodies subjective agency, why is she/he/it not human? The attempts in the boy-meetsmecha narratives to define a future version of humanity accord better with an alternative view that the posthuman does not necessitate either an evolution or devolution of the human. Rather it means that difference and identity are being redistributed. Ideas of humanity - that is, 'the human' - naturalise and hierarchise difference within the human (whether according to race, class, gender) and make absolute distinction between human and nonhuman. Ideas of the posthuman question what we consider to be 'natural', and create possibilities for the emergence of new relationships between human and machine, biology and technology.
Relating to and understanding a mechanoid thus pivots on matters of ontology rather than epistemology, and Hideki is therefore much better equipped to shape humanity's posthuman future than are the techno whiz-kids who ultimately must learn from him. The model for such learning is embodied in twelve-year-old techno genius Minoru, who can build a persocom in the physical image of his dead sister, and program her with his sister's 'data', but only learns the quality of human love when Hideki prompts him to realize that he loves Yuzuki for herself, and not for his sister implanted within her. When Yuzuki crashes and loses that data from memory, Minoru has become ready to decide not to input it again (7, pp.19-29).

Minoru's brotherly love for Yuzuki reflects the ideology driving the series: cathexis itself must be grounded in ontology rather than epistemology. Chii has been programmed to seek 'Someone who will love me because I am me' (7, p.154), and if her quest proves unattainable the world will become an unperceiving machine. Hideki thus undergoes a classic folktale test: he does not recognise the quest he is engaged in, and must reach its outcome without knowing what the stakes are. When he first acquires Chii, he thinks of her as an object. Her initial behaviour after being awakened is to imitate physical gestures and postures, and when Hideki finds her looking at one of his porn magazines and imitating the poses of the girls in the magazine, he becomes sexually aroused, but immediately corrects himself: 'It's a machine. Like a toaster or a microwave' (1, p.39). The imbrication of pornography and mechanoid in this early moment in the series begins to define the issues that will unfold throughout. Which image more strongly invokes desire - the naked woman in the magazine, or the partly clothed mechanoid imitating it? Which image is more intensely objectified? Chii's performance of a version of femininity constructed for the male gaze both satirizes this pornographic tendency in manga and glances at the negative interpellative effects of particular discourses of femininity. Hideki, however, will move on from this point to engage with deeper questions. What is the place of physical desire in cathexis? What takes priority, love or desire?

Like other contemporary boy-meets-mecha manga, the Chobits series affirms the idea of a 'perfect match', but 


\section{These manga have, for western readers, a double strangeness.}

grounds this in intersubjective, trustworthy friendships. Video Girl Ai - especially the manga version - offers an instructive comparison. The male protagonist, Yōta Moteuchi, is another warm, caring schoolboy lacking in self-confidence. Having discovered that Moemi, the girl he loves, is in love with his best friend, Yōta disconsolately enters a mysterious video shop, Gokuraku (paradise), which is only visible to a pure and caring boy with a broken heart. He borrows what he thinks is a porn tape, 'I will comfort you: Amano Ai'. Normally when this tape is played, a sensual young woman (Ai) materializes from the screen and offers sexual solace to the viewer. But Yōta's video player is defective, and Ai materializes not as a feminine, sexually attractive girl, who is also a skilful cook, but with a thin, boyish body, rough, boyish speech and a propensity for mischief (and is unable to cook). She is possessed of genuine rather than simulated warmth, however, and the two evolve a non-sexual friendship that eventually develops into love. The crux of this elaborate narrative is the question of whether 'love' truly exists. The creator of the video girls (a humanoid from the future who grew up without knowing human/parental love $(12$, p. 167) insists love is only a narcissistic illusion, and the ultimate purpose of the video girl system is not to help a young man with a pure heart to recover the ability to love but to teach him, through experiencing the 'comfort' offered by a physically desirable, sexually skilful, yet unemotional video girl, that (spiritual) love is fragile, transient and untrustworthy. As in Chobits, the boy's love for the programmed, non-human girl is critically tested, with both having to overcome memory erasure (and a video girl who experiences genuine cathexis will be recalled and destroyed as defective), but the manga ends happily when Yōta and Ai respectively fight to regain their erased memories and affirm their love for one another ${ }^{12}$. Video Girl Ai includes some explicit depictions of Ai's naked body - far more explicit than any images in Chobits or A.I. Love You - and while these no doubt do offer a certain frisson for the male gaze, their thematic function is to privilege intersubjective love over physical desire. It is clearly assumed that the warm yet non-sexual touches (for example, hugging or holding hands) that convey genuinely romantic and spiritual love, exist in common with the essential element of familial love. Yuzuki gives Minori a hug when he is sad. Yuzuki's conservative dress also indicates that her value is fundamentally different from Minoru's other persocoms, who are scantily clad in overtly sexual costumes. As Kusaka asserts, although abundant sexual references and displays occur in manga and animé, sex with one's true love (the perfect partner) is taboo in love comedies (Kusaka 2000, pp.61-62). This is also the key to Hideki's quest in Chobits.

The conjunction of pornographic and mechanoid images in these works functions as a sign for a society that, in Yoneyama's (1999) term, is 'program-driven', in which the mechanoid or non-human is a metaphor for the generation that has emerged since the early 1990s. A generation that relies on manuals and instruction books is caricatured in Video Girl Ai when Ai tricks Yōta into studying a manual in preparation for love-making. A similar joke about manuals underlies the scene from Chobits discussed above, in that while Hideki is looking for his copy of Persocoms for Dummies, Chii is engrossed in his porn magazine. The conjunction, however, also becomes the field in which the materialist society can be challenged by the unexpected. This element of unexpectedness enables both humans and mechas (persocoms, video girls, artificial intelligences) to develop their own subjectivities and discover who they really are. As Chii learns and develops, her secret past begins to emerge. She was originally named Elda, and she and her older sister Freya are 'chobits', persocoms with almost legendary status in the domain of cyberspace. The rumours about them are summed up by Minoru: 'Chobits are said to be artificial intelligences capable of thinking and acting on their own' $(1, \mathrm{p} .84)$. They were created as surrogate children by a genius, Ichirō Mihara, for his childless wife, Chitose Hibiya. Crucially, they were programmed to love. Freya, however, tragically grows to love her father/creator, Ichirō, and, in a mark of her humanness, dies/breaks irrecoverably of a broken heart. Just before Freya dies, Elda transfers her data/soul into herself, then asks her parents to erase her data so that she can be born again to find her own 'someone just for you', but not remember her creator/father.

The process of naming here is something of a tease, but may point to an observation made by Graham (2002, p.9) that the construction of fiction by blending myth and technology helps 'to reinject the spiritual, the religious and 


\section{It produces 'the rational subject, the subject of calculating mastery...'.}

the "transcendent" into a materialist world'. This is more obvious with the trio of goddesses in Ah! My Goddess: Urd, Skuld and Belldandy are based on the (obscure) Nordic fates (roughly, Fate, Future and Present, respectively) ${ }^{13}$ to whose power over time and process even the gods are subject. The heavenly bride motif in these stories is another blending of myth and technology, but is perhaps reinforced in Chobits by naming the two unique persocoms Freya and Elda: the purpose of the first seems obvious - the goddess of fertility as a sign that the infertility of their 'mother', Chitose Hibiya, has been overcome; the second is perhaps an oblique case of eldi 'something born', whereby the difference between the born and the made is collapsed. As remarked previously, Chobits depicts cathexis as the force which effects that erasure. It is presented quite explicitly when Ms Hibiya recounts to Hideki her feelings of sorrow and grief when an earlier form of humanoid computer 'broke' and her husband's explanation: 'It's only natural. Even if they aren't alive, you are. You care because you are alive - because you have a heart' (7, p.105). A further mythic element deployed in Chobits and A.I. Love You, and which merits further investigation, is the Pygmalion motif, whereby a love relationship develops between a male creator and a female created object which becomes human. The motif is most overtly handled in the romantic comedy series A.I. Love You, in which the opening episode depicts Hitoshi enacting the Pygmalion story as he talks with and imagines adorning the perfect women he has created as an A.I. program, and then she is embodied by means of a lightning strike. A recurrent theme of the series is that Hitoshi/Pygmalion has to rise above seeing Saati/Galatea as a predominantly physical object — a lesson he re-learns in numerous episodes.

The desire to recuperate transcendence is an overt response to a sense that humanity has become misplaced, if Viviane Casimir's remark that 'both machine and human are information-processing systems' is taken at face value (Casimir 1997, p.282). Through the modern era, reason has become entrenched as the predominant mode of human social practice, and the rule of rational-technical instrumentality has accordingly eroded the affective realm of social action (see Graham 2002, p.6). Burfoot argues that 'posthumanism, especially as formulated in technoscience, can be seen to reify the objectification of the body in terms of denying its formative role and by affirming it as irreducible atomic matter' (2003, p.48). The manga seek to redress this situation by configuring three kinds of character.

First, the mecha herself is endowed with a formative role and a capacity for learning. Chii is virtually a blank slate after Hideki switches her on, 'like a child ... [who] knew nothing of the world' (7, p.113). As she accumulates information through lived experience and discursive materials (especially Ms Hibiya's City with No People picture book series about the nature of being in the world), rather than through programming (she is, in fact, immune to digital programming), she engages in increasingly sophisticated modes of intersubjective relationship. Like Ai (Video Girl $A i$ ) and Saati (A. I. Love You), her 'humanity' is constituted by her capacity for cognitive processes, for experiencing joy and sorrow, for experiencing deep emotion, especially love, and for feeling and acting upon altruistic impulses. In short, she can be attributed subjectivity. Ai and Saati, however, need to temper high-level programming with a learned innocence: Ai, by losing the sophisticated sexuality metonymized by her voluptuous body (her breasts shrink dramatically when she materializes); and Saati becomes more human by becoming less rational. In Saati's case this is dramatized in Volume 3 (pp.129 ff.) in an incident with a stray puppy. When she realizes that the puppy is not yet weaned, her first confused action is to attempt to breastfeed it. The depiction of her near-naked upper body, coupled with Hitoshi's exclamation, 'You ... you can't breastfeed a puppy!!', shapes and registers the audience's shock and repulsion at her action, and shows that the audience is already thinking of her in human terms. She dresses the puppy in human baby clothes when she applies reason and consults a manual, but subsequently, when she feels unwillingness to return the puppy to his owners Hitoshi explains, 'You've become a little bit more human than before' $(3, \mathrm{p} .158)$.

The second kind of character that functions to interrogate the rule of rational-technical instrumentality is the ingenuous male such as Hideki and Yōta. Their basic incompetence with technology, and their propensity to display a range of more volatile emotions than other characters, privileges human emotion over matter and reaffirms the force of 


\section{The constraints grow out of the cultural context and so are profoundly ideological.}

affective social action. The third type is exemplified by Minoru (Chobits) and Hitoshi (A. I. Love You), who possess both rational minds and a very high level of skill with computers, but nevertheless remain sensitive to emotions and capable of deep intersubjective relationships.

The mecha in these stories blur the distinction between organism and machine. Since, as Casimir (1997, p.282) suggests, "The question of the "living" is a question of subjectivity', the mechanoids represented here both illustrate this and call into question the 'humanity' of organic life forms. Each of the mechas is a bodily entity who undergoes a childlike development of her own presence in space and time. Each is depicted as a body endowed with life, threatened with non-being, as each experiences multiple crises which threaten to erase her. Each is depicted as unique, a self existing in a network of intersubjective relationships, and the difference from others in that network which define them incorporate both differences as persocoms and personal differences. Finally, each of the mechas is represented as a thinking subject, who conceives of herself as a unity, and whose childlike innocence endows her with a potential for subjective agency because it positions her outside of her society's propensity to represent itselfas always already instituted, and therefore denying the possibility of other versions of being. Once the computer has acquired subjective agency, she has through intersubjective relationships the capability for either selfalteration or remaking the world. Such a transformation of subjectivity has implications for those female readers who align themselves with the warmth and innocence of these protagonists, and perhaps in part explains why $\mathrm{Ai}$ is so popular amongst visitors to Katsura's website: from 2001 to 2003 they have consistently voted her number two amongst the characters Katsura has devised. For the predominant male readership, on the other hand, it models a more emotionally considerate and less sensually driven way of thinking about and relating to girls.

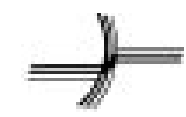

\section{NOTES}

1. For example the use of Poke-beru (Pocket bell/pagers) then Keitai (mobile phones) became a phenomenon amongst Japanese high school girls, and the technology used to facilitate encounters with unknown people through mobile phones. For the active roles of information technologies in Japanese interpersonal relationships, see Japanese Cyberculture, edited by Gottlieb and McLelland, 2003.

2. From her survey (questionnaires) for high school students in 1993 regarding the gender roles in manga, Tanimoto concludes that the students' perception of desired images are conservative: desired male characters are endowed with abilities, initiative and are able to do things you cannot, whereas desired female characters are amiable and friendly (Tanimoto 1998). Ōtsuka also found in his interviews that postwar baby boomers' children are not suspicious or cynical about 'family' and accepted the 'family image/illusion' (Ōtsuka 1990).

3. Swan maiden tales, which are ancient and found in many parts of the world (see Hatto 1961), reached Japan in the third or fourth century, with the protagonist imaged in one of two ways: as bird maidens (often cranes), and as heavenly women dressed in white, silky, long clothing like hiten (flying, music-playing heavenly being/Buddhist deities on Hōryūji temple's wall paintings). The latter, the celestial maiden with Hagoromo continuously evolved intertextually, creating abundant stories, from Princess Kaguya's Taketori monogatari ("Tale of the Bamboo Cutter") in the late ninth century (Kanda 1963), Zeami's famous Noh play Hagoromo in the medieval period, and the folktale from China, of Orihime (the Weaving Princess, Vega), who was drawn back to the heavens against her will and only allowed to meet with her husband on the night of Tanabata (the Star festival), Vega and Altair. Yù Watase's manga, Ayashi no Ceres (14 volumes 19962000 ), is one of the most recent productions in this stream. Napier (2000) has identified a "magic girl" motif in manga/animé stories, but our argument is that there is a more archaic metanarrative at work. 
4. CLAMP is a very successful team of four woman manga artists (Ageha Ohkawa; Satsuki Igarashi; Tsubaki Nekoi and Mokona Apapa), continuously producing stylish, elaborate and entertaining works in a wide range of areas, including Cardcaptor Sakura, X, Wish and xxxHolic.

5. The title of the Japanese original is AI ga tomaranai! (Ai [Artificial Intelligence/Love] does not stop!), first published in Shükan Magazine (Weekly Magazine) from 1994 to 1997.

6. The Japanese title is Den'ei Shōjo: Video Girl Ai (lit. electronic shadow girl). There are two more volumes of Den'ei Shōjo, which contain short stories not about Ai. The English version of Video Girl Ai was published by Viz Communications, Inc., from 1999.

7. Video Girl Ai first appeared in Shūkan Shōnen Jump (Weekly Boys' Jump, hereafter Jump) between 1989 and 1992. This magazine started in 1968 and has been the most popular and successful weekly boys' manga magazine. It is said that the Jump's publication policy is based on three keywords - friendship, effort and winning - chosen by 10 and 11 years old boys. Its original target readers were therefore boys. Although the readership has extended to adults, Jump still targets boys, which restricts it from depicting real sex, despite its abundant provocative sexual references. Many girls also read Jump. Its print-run had reached 5,000,000 copies by 1989, when Video Girl Ai started. Jump's publication practices are influenced by constant reader rankings and if a manga cannot achieve popularity by the $10^{\text {th }}$ week, it may be discontinued. Video Girl Ai contains 115 chapters, which demonstrates its popularity. For Jump, see Saitō 1996; Schodt 1996, pp.87-91)

8. Chobits was originally published from 2000 to 2002, in Kōdansha's Shūkan (Weekly) Young Magazine, which is categorised as "seinen-shi" (magazines for young adult males).

9. Thus in an interview with Fujimoto's interview, Nariko Enomoto (manga artist) ponders whether Video Girl promotes the idea that if becoming human depends on being loved by a man, then a woman who is not loved by a man/men is not a woman (Fujimoto 2000, p.181).
10.In vol 7 of AI ga tomaranai, episodes 46-48 involve a school play using a mermaid story (which, in Japan, is known mostly through Hans Christian Anderson's Little Mermaid). In the play, Saati plays a mermaid and is forced by Cindy (a human girl who likes Satoshi) to promise that she will disappear if she fails to win the love of the prince (acted by Satoshi). Saati relates her situation as a non-human with the mermaid and when Satoshi on the stage chooses a human girl, acted by Cindy, she tries to disappear, by destroying her core programs.

11.Cute images may be ambiguous, ambivalent and complicated, because of the integration of adorable innocence (fragile yet spiritual and sacred) with prettiness in body and behaviours (either childlike/ childish, comical or possibly sexually attractive). Although it can easily be stereotyped and commodified, cuteness enriches a story by injecting light-heartedness into the relationship, and by triggering the boy's affection as a protector/nurturer it eludes the more familiar pattern of relationships modelled on mother-son relationship, which has pervaded Japanese films (Satō T. 1982). A passion for 'cuteness' is prevalent not only in manga and animé but also in Japanese society, indicating deepseated, nostalgic desires for a dreamed childhood and an implicit refusal of adulthood, which is often felt as a heavy burden of responsibility and social conformity, rather than offering the joy of independence (see, for example, Ōtsuka 1991; Masubuchi 1994; Kinsella 1995; Machizawa 1999).

12.Katsura states that his original intention was the unhappy ending involving Ai's disappearance, but he changed his mind, partly because of readers' requests not to erase Ai (vol.13, p.191).

13. Belldandy is a version of the name of the third fate, Verđandi (literally, 'becoming'), apparently produced by Japanese consonant substitutions $(\mathrm{v} \rightarrow \mathrm{b}, \mathrm{r} \rightarrow \mathrm{l})$.

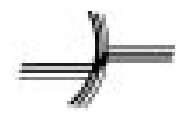




\section{REFERENCES AND FURTHER READING}

Algarin, Joanne P. (1982) Japanese Folk Literature: A Core Collection and Reference Guide. New York and London, R. R. Bowker Company.

Akamatsu, Ken (2000) Shinsōban AI ga Tomaranai! (New edition, A.I does not stop!) vol.7, Tokyo, Kōdansha.

Akamatsu, Ken (2004) A.I. Love You, Los Angeles. Tokyo and London, Tokyopop.

Burfoot, Annette (2003) 'Human remains: Identity politics in the face of biotechnology', Cultural Critique 53: 47-71.

Casimir, Viviane (1997) 'Data and Dick's deckard: Cyborg as problematic signifier', Extrapolation 38, 4: 278-291.

CLAMP (2001-2002) Chobits (8 volumes), Tokyo, Kōdansha; (2002-2003), Chobits (8 volumes). Los Angeles, Tokyo and London, Tokyopop.

Fujimoto Yukari (2000) Shōjo manga damashii (girls manga souls). Tokyo, Hakusensha.

Fujishima, Kōsuke (2000) Ah! My Goddess: The Movie. Kodansha/Madman.

Gottlieb, Nanette and McLelland, Mark eds. (2003) Japanese Cybercultures. London and New York, Routledge.

Graham, Elaine L. (2002) Representations of the Post/human: Monsters, Aliens and Others in Popular Culture. Manchester, Manchester University Press.

Gray, Chris Hables (2002) Cyborg Citizen. New York and London, Routledge.

Hatto, A. T. (1961) 'The Swan Maiden: A folk-tale of north Eurasian origin?', Bulletin of the School of Oriental and African Studies 24, 2: 326-352.

Hoogland, Renée C. (2002) 'Fact and fantasy: The body of desire in the age of posthumanism', Journal of Gender Studies 11, 3: 213-231.
Kanda, Hideo (1963) 'Hagoromo setsuwa' (Hagoromo tales), in Minzoku no Koden (Kanda Hideo ronkōshū vol.4). Tokyo, Meiji shoin, 1984, pp.218-235.

Katsura, Masakazu (1990-1992), Den'ei shōjo: Video Girl Ai (13 volumes). Tokyo, Shūeisha.

Katsura Masakazu Dōmei (Union) http://www.ipctokai.or.jp/ stom/rank/rank.html

Kawai, Hayao (1982) Mukashibanashi to nihonjin no Kokoro. Tokyo, Iwanami shoten.

The Japanese Psyche: Major Motifs in the Fairy Tales of Japan (1992), Connecticut, Spring Publications.

Kinsella, Sharon (1995) 'Cuties in Japan' in Lise Skov \& Brian Moeran (eds) Women, Media and Consumption in Japan. Honolulu, University of Hawai'i Press, pp. 220-254.

Kusaka, Midori (2000) Manga-gaku no susume (recommendation of study of manga). Tokyo, Hakuteisha.

Machizawa, Shizuo (1999) Seijuku dekinai wakamono-tachi (Young people who cannot mature/grow adult). Tokyo, Kōdansha.

Masubuchi, Sōichi (1994) Kawaii shōkōgun (cute syndrome). Tokyo, Nihon hōsō shuppan kyōkai.

Miyadai, Shinji (1994) Seifuku shôjo-tachi no sentaku (Choices of girls in school uniforms). Tokyo, Kōdansha.

Murakami, Tomohiko (1998) Manga kaitai shinsho: Tezuka Osamu no inai hibi no tame $n i$ (Analysis of Manga: for the days without Tezuka Osamu). Tokyo, Seikyūsha.

Nagase, Tadashi (1996) Nikutai no Neutopia: Robot, Powered Suit, Cyborg no Kōkogaku (Neutopian Flesh: Archaeology of Robots, Powered Suits, Cyborgs). Tokyo, Seikyūsha. 
Napier, Susan J. (2000) Animé from Akira to Princess Mononoke: Experiencing Contemporary Japanese Animation. New York, Palgrave.

Ogi, Fusami (2001a) 'Gender insubordination in Japanese comics (Manga) for girls', J. A. Lent (ed) Illustrating Asia: Comics, Humour Magazines, and Picture Books. Honolulu, University of Hawaii Press, pp.171-186.

Ogi, Fusami (2001b) 'Beyond Shoujo, blending gender: Subverting the homogendered world in Shoujo Manga (Japanese Comics for Girls)', International Journal of Comic Art, 3, 2: 151-161.

Ōhira, Ken (2000) Jun 'ai jidai (Period of pure love). Tokyo, Iwanami shoten.

Orbaugh, Sharalyn (2003) 'Busty battlin' babes: The evolution of the Shojo in 1990s visual culture', in Joshua S. Mostow, Norman Bryson, \& Maribeth Graybill (eds) Gender and Power in the Japanese Visual Field. Honolulu, University of Hawaii Press, pp. 201-228.

Ōtsuka, Eiji (1990) 'Kazoku wa hōkai shite inai no kamo shirenai' ('Family' might not have collapsed', originally in Hon no zasshi (Book magazine) then included in Ōtsuka's 'Iyashi' to shite no shōhi (Consumption as 'healing'). 1991, Tokyo, Keisō shobō, pp.262-268.

Ōtsuka, Eiji (1991) “"Kawaii” no tanjō' (The Origin of Cuteness/Cute Culture), in Ōtsuka Eiji (ed) Shōjo zassi ron (Discussion of girls' magazines). Tokyo, Tokyo shoseki, pp.85102.

Saitō, Jirō (1996) Shōnen Jump no jidai (Period of Boys' Jump). Tokyo, Iwanami shoten.

Sato, Kumiko (2004) 'How information technology has (not) changed feminism and Japanism: Cyberpunk in the Japanese context', Comparative Literature Studies, 41, 3:335-355.
Satō, Tadao (1982) Currents in Japanese Cinema, trans. by Barrett Gregory. Tokyo, Kodanshan International.

Schodt, Frederik L. (1996) Dreamland Japan: Writings On Modern Manga. Berkeley, California, Stone Bridge Press.

Tanimoto, Naho (1998) 'Dokusha ankeōto ni miru Manga no seisa' (Sexual differences in manga from readers' questionnaires) in Kyōto Seika Daigaku jōhōkan (ed.), Kino hyōron: Bungaku wa manga ni maketa ka (Kino Review Special edition, Was literature defeated by manga?), pp.160-166.

Yokomori, Rika (1996) Ren'ai wa shojo manga de osowatta (I learnt love from girls' manga). Tokyo, Crest-sha.

Yoneyama, Shōko (1999) The Japanese High School: Silence and Resistance. New York and London, Routledge.

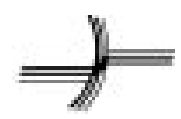

\section{BIOGRAPHICAL NOTES}

John Stephens is professor in English at Macquarie University. He is the author/coauthor of two books about discourse analysis, two books about children's literature, and around sixty articles. Most recently he has edited Ways of Being Male: Representing Masculinities in Children's Literature and Film (2002). Current research is focused on the impact of 'new world orders' on children's literature since 1990 .

Mio Bryce is Lecturer in Asian Languages at Macquarie University, teaching Japanese language, literature and 'Japan's Contemporary Culture through Manga'. She holds a $\mathrm{PhD}$ in Japanese classical literature (on The Tale of Genji), from the University of Sydney. 